\title{
Asymmetry of high-velocity lower crust on the South Atlantic rifted margins and implications for the interplay of magmatism and tectonics in continental breakup
}

\author{
K. Becker ${ }^{1}$, D. Franke ${ }^{1}$, R. Trumbull ${ }^{2}$, M. Schnabel ${ }^{1}$, I. Heyde ${ }^{1}$, B. Schreckenberger ${ }^{1}$, H. Koopmann ${ }^{1}$, K. Bauer ${ }^{2}$, \\ W. Jokat ${ }^{3}$, and C. M. Krawczyk ${ }^{4}$ \\ ${ }^{1}$ Federal Institute for Geosciences and Natural Resources (BGR), Hannover, Germany \\ ${ }^{2}$ German Research Centre for Geosciences (GFZ), Potsdam, Germany \\ ${ }^{3}$ Alfred Wegener Institute (AWI), Bremen, Germany \\ ${ }^{4}$ Leibniz Institute für Applied Geophysics (LIAG), Hannover, Germany
}

Correspondence to: K. Becker (becker007@gmx.de)

Received: 7 May 2014 - Published in Solid Earth Discuss.: 10 June 2014

Revised: 29 August 2014 - Accepted: 2 September 2014 - Published: 2 October 2014

\begin{abstract}
High-velocity lower crust (HVLC) and seawarddipping reflector (SDR) sequences are typical features of volcanic rifted margins. However, the nature and origin of HVLC is under discussion. Here we provide a comprehensive analysis of deep crustal structures in the southern segment of the South Atlantic and an assessment of HVLC along the margins. Two new seismic refraction lines off South America fill a gap in the data coverage and together with five existing velocity models allow for a detailed investigation of the lower crustal properties on both margins. An important finding is the major asymmetry in volumes of HVLC on the conjugate margins. The seismic refraction lines across the South African margin reveal cross-sectional areas of HVLC 4 times larger than at the South American margin, a finding that is opposite to the asymmetric distribution of the flood basalts in the Paraná-Etendeka Large Igneous Province. Also, the position of the HVLC with respect to the SDR sequences varies consistently along both margins. Close to the Falkland-Agulhas Fracture Zone in the south, a small body of HVLC is not accompanied by SDRs. In the central portion of both margins, the HVLC is below the inner SDR wedges while in the northern area, closer to the Rio Grande Rise-Walvis Ridge, large volumes of HVLC extend far seaward of the inner SDRs.

This challenges the concept of a simple extrusive/intrusive relationship between SDR sequences and HVLC, and it provides evidence for formation of the HVLC at different times
\end{abstract}

during the rifting and breakup process. We suggest that the drastically different HVLC volumes are caused by asymmetric rifting in a simple-shear-dominated extension.

\section{Introduction}

A lower crustal zone with high density and high seismic $P$-wave velocity is part of the magmatic "trinity" that characterizes volcanic rifted margins: continental flood basalts, seaward-dipping reflector (SDR) sequences and high-velocity lower crust (HVLC) (e.g., Menzies et al., 2002; White et al., 1987; Talwani and Abreu, 2000). There is no set definition for "high velocity" in this context, but here we use a cutoff value of $7 \mathrm{~km} \mathrm{~s}^{-1}$ as "normal", based on the $\mathrm{Vp}$ values of unaltered gabbroic oceanic crust (layer 3: $6.8-7.1 \mathrm{~km} \mathrm{~s}^{-1}$ after Mooney et al., 1998). Thus, the HVLC has a $P$-wave velocity (and density) greater than that of typical oceanic lower crust. In general, HVLC at volcanic rifted margins is thought to represent magmatic (gabbroic) intrusions and related cumulate layers (Farnetani et al., 1996; Furlong and Fountain, 1986; Kelemen and Holbrook, 1995; White and McKenzie, 1989; Thybo and Artemieva, 2013). Alternatively, HVLC may represent serpentinized peridotite (O'Reilly et al., 1996) or dense metamorphic rocks (Gernigon et al., 2004; Mjelde et al., 2013). 
The lower continental crust of cratons or shields may have velocities exceeding $7 \mathrm{~km} \mathrm{~s}^{-1}$ (Rudnick and Fountain, 1995).

A common assumption describes a close spatial relationship between the SDRs and HVLC, whereby the HVLC represents intrusive equivalents of the erupted lavas which form the SDRs (White et al., 2008; White and Smith, 2009; Blaich et al., 2009). HVLC can make up a large part of the total magmatic output along volcanic rifted margins, and as studies in the North Atlantic have shown, variations in size and physical properties of the HVLC in these settings hold important clues to mantle melting scenarios (Fernàndez et al., 2010; Kelemen and Holbrook, 1995; Korenaga et al., 2002; Ridley and Richards, 2010; Voss et al., 2009; White et al., 2008). Alternatively, it might be speculated that portions of the HVLC form postrift (Franke, 2013).

The presence of HVLC bodies along the South Atlantic rifted margins is well established from seismic and gravity studies (e.g., Bauer et al., 2000; Blaich et al., 2011; Franke, 2013; Franke et al., 2010; Maystrenko et al., 2013; Schnabel et al., 2008), but they have not yet been studied for areal extent and rifting process determination. That is the purpose of the study reported here. We provide seismic velocity and gravity models for two new margin profiles in South America and integrate them with five others into a regional interpretation of breakup and magmatism in the South Atlantic. The emphasis is on variations in the size and $P$-wave velocities of the HVLC along the South American and African margins, and on their distribution relative to the SDRs. We demonstrate a much stronger development of HVLC bodies on the African margin than on the conjugate margin of South America, whereas the distribution of surface volcanism in the Paraná-Etendeka flood basalt province shows exactly the opposite sense of asymmetry. The development of SDR sequences is roughly symmetrical, and there are variations in the relative position of HVLC bodies with respect to the SDRs which question a simple intrusive vs. extrusive relationship and have implications for the timing of HVLC formation relative to rifting and breakup.

\section{Geologic framework}

For the interpretation of the origin of HVLC on the conjugate margins of the South Atlantic (in Sect. 5.1), it is useful to summarize the onshore geology of the continental crust. The coastal zone on both margins is underlain by Neoproterozoic mobile belts and/or Paleozoic fold belts which border older cratonic provinces farther inland (see Frimmel et al., 2011, for a review). On the South American margin, the Neoproterozoic crust at the Atlantic margin is part of the Dom Feliciano Belt, which separates the inland Rio de la Plata Craton from the coast. Much of the Dom Feliciano Belt is composed of intermediate meta-igneous rocks that represent a magmatic arc which was accreted to the inland basement terranes (Frimmel et al., 2011). Seismic line 1 crosses the
Neoproterozoic arc terrane on the Uruguay margin, whereas lines 2 and 3 cross the broad Argentine continental shelf at or south of the Colorado transform fault, an area whose basement geology is buried by younger rocks.

On the conjugate margin of South Africa, the coastal zone is underlain by the Neoproterozoic Kaoko, Damara and Gariep belts (from north to south, respectively). These are bordered on the east by older, Mesoproterozoic metamorphic units of the Namaqua-Natal Mobile Belt and, still farther inland, by the Kalahari Craton. On the southern end of the margin the Neoproterozoic rocks are overthrust by mainly Paleozoic sedimentary rocks of the Cape Fold Belt, which resulted from northward-directed convergence in Permian and Carboniferous times. With respect to these basement features, the onshore parts of seismic lines 4 and 5 lie within the Damara Belt, whereas lines 6 and 7 cross the Gariep Belt at the coast and extend into the Namaqua-Natal Mobile Belt to the east. The seismic traverse across the southern margin of Africa (Stankiewicz et al., 2008) crosses the Cape Fold Belt and extends into the Namaqua-Natal Mobile Belt to the north (line 8 in Fig. 1).

The key point about the regional geology of the South Atlantic margins is that the zones of HVLC detected by geophysics are located beneath the current coastline or farther seaward, so only the Neoproterozoic belts near the margins are potentially relevant for explaining the crustal velocities. None of the seismic traverses on either margin extend inland as far as the cratons.

The South Atlantic Ocean formed as a consequence of the breakup of Western Gondwana in Early Cretaceous times (ca. 140-130 Ma). South of the Walvis Ridge-Rio Grande Rise, the volcanic trail generated by the mantle plume Tristan da Cunha, most of the continental margins of the South Atlantic are of the typical volcanic rifted type, with welldeveloped SDR wedges and HVLC bodies mentioned above. However, the nature of the margins changes abruptly beyond these limits. North of the Walvis Ridge-Rio Grande Rise, the margin architecture resembles the end member of a magma-poor margin (Mohriak and Leroy, 2012). HVLC at the West African Angolan margin thus was interpreted as being likely unrelated to breakup (Contrucci et al., 2004). Still another style of margin occurs at the Falkland-Agulhas Fracture Zone (FAFZ) in the south (Fig. 1), where the South Atlantic rifting likely was accommodated by strike-slip displacement to form a margin that is lacking SDRs and other signs of magmatism (Becker et al., 2012; Franke et al., 2007; Koopmann et al., 2014a).

In contrast to the rifted volcanic margins in the North Atlantic, the geology and spreading history of the South Atlantic (between the FAFZ and the Walvis Ridge-Rio Grande Rise) is comparatively simple. There are no major ridge jumps as found in the Greenland-Iceland Ridge, and the opposing continental margins have a broadly similar geologic history. The margins of East Greenland and Norway are shaped by the Caledonian orogen, post-Caledonian basins 


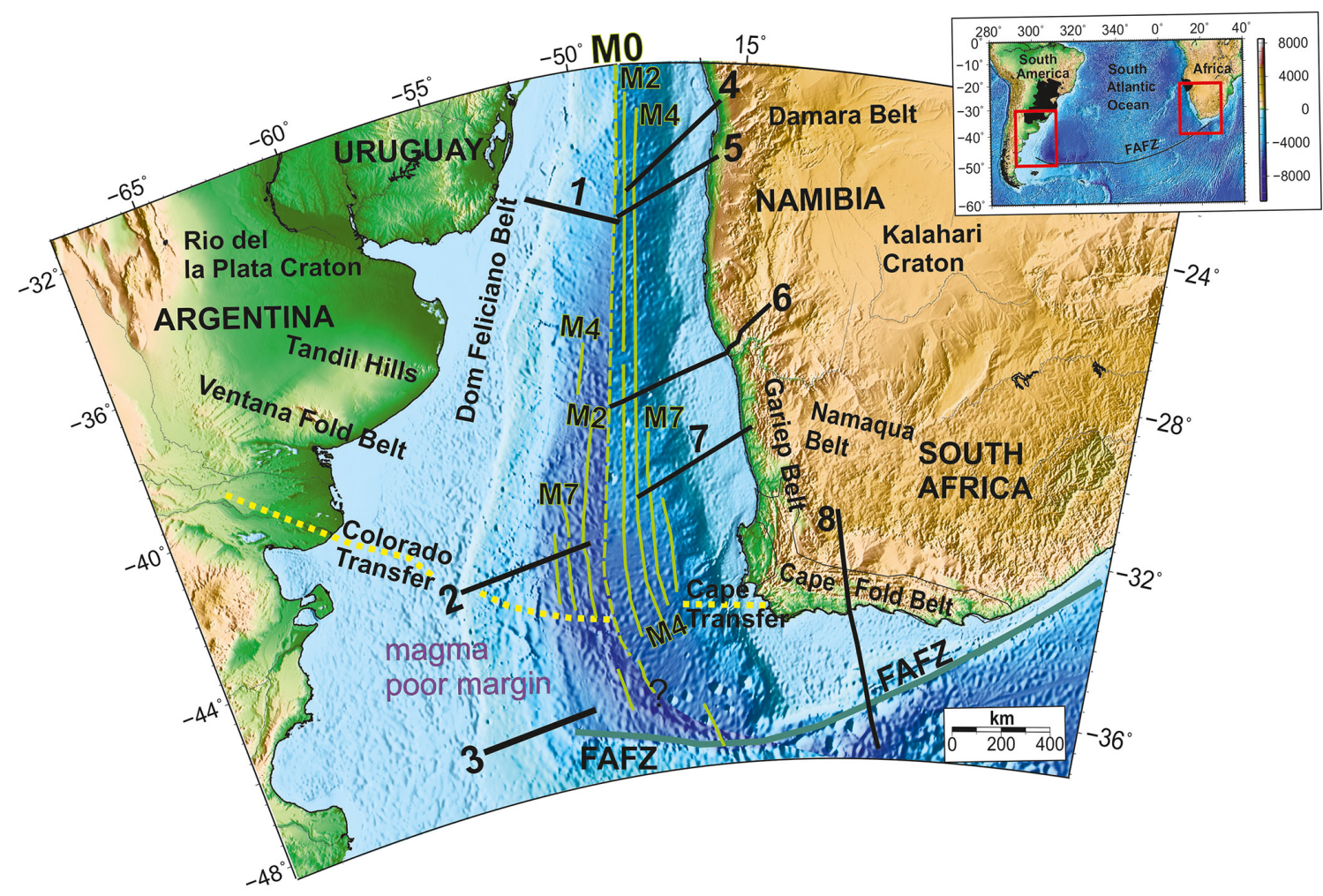

Figure 1. The southern South Atlantic Ocean aligned along magnetic seafloor-spreading anomaly M0 (dashed green line; ca. $125 \mathrm{Ma}$ ). The continental margins between the Falkland-Agulhas Fracture Zone (FAFZ) and the Colorado-Cape transfer zone lack major magmatic extrusives and are indicated as magma-poor. The margins to the north of the transfer zone are volcanic rifted margins with extensive seawarddipping reflector (SDR) wedges and high $P$-wave velocities in the lower crust. Black lines show the location of the refraction seismic lines discussed in the text: line 1 (BGR04-01), line 2 (BGR98-02), line 3 (BGR04-02), line 4 (Mamba 1), line 5 (Mamba 2), line 6 (Orange River), line 7 (Springbok) and line 8 (Agulhas-Karoo transect). Magnetic anomalies are shown as green lines. The inlay shows the present-day South Atlantic Ocean, with the black areas marking the distribution of the Paraná-Etendeka flood basalts.

and flood basalts. The asymmetry in the crustal structure of the conjugate margins, as well as a complicated tectonic interplay of magmatism and geological features, like lineaments and/or metamorphic rocks (eclogites) inherited from the Caledonides, suggests a complex rifting evolution and postrift events (Voss and Jokat, 2007; Mjelde et al, 2003). The timing of South Atlantic opening was diachronous, progressing from south to north (Austin and Uchupi, 1982; Blaich et al., 2011; Franke, 2013; Franke et al., 2007; Jackson et al., 2000; Rabinowitz and LaBrecque, 1979; Sibuet et al., 1984; Koopmann et al., 2014a). The use of seafloor magnetic anomalies to date this process is complicated by uncertainties in anomaly picks for the southern margins. A recent detailed investigation by Koopmann et al. (2014b) proposed that the oldest magnetic anomaly offshore of Argentina and South Africa related to oceanic spreading is M9r (ca. $135 \mathrm{Ma}$, using the Geologic Time Scale 2012 (GTS 2012; Gradstein et al., 2012). Rabinowitz and LaBrecque (1979) suggested that M9N and M11 (133 and 136 Ma, respectively) are the oldest spreading anomalies, whereas others mentioned M7 as the earliest anomaly. There is less debate about spreading anomalies in the northern margin areas of the Walvis Basin, where M4 (ca. 130 Ma) is the oldest spreading anomaly. Anomaly M4 can be mapped along the entire margin (Fig. 1), and this will serve in the present study as a time marker for the regime of seafloor spreading in oceanic lithosphere.

Onshore, by far the largest concentration of magmatic activity was in the Paraná-Etendeka province of Brazil and Namibia, where considerably more than $10^{6} \mathrm{~km}^{3}$ of continental flood basalts and related silicic volcanic units were erupted in the time span of about 134-126 My (Peate, 1997). We do not discuss the complex topic of magma generation and evolution here, but point out that there is a great deal of information and much controversy about the source of magmas in the Paraná-Etendeka province and the role of the Tristan plume in producing them (see Peate et al., 1999; Hawkesworth et al., 1999; Trumbull et al., 2003; Ewart et al., 1998; Comin-Chiaramonti et al., 2011). The distribution of lavas offshore, represented by the SDR wedges, shows that magmatism was not only concentrated in the north but in fact extended along both margins to the Colorado-Cape Fracture Zone (Franke et al., 2007; Becker et al., 2012; Koopmann et 
al., 2014; Gladczenko et al., 1997) (Fig. 1). On the South African margin onshore, mafic dikes of breakup age occur as far south as Cape Town. A comparative geochemical study of mafic dikes along the African margin (Trumbull et al., 2007) demonstrated a north-south decrease in crystallization temperatures by about $150^{\circ} \mathrm{C}$, which is important when discussing the variations and possible origin of HVLC in a later section. Finally, widespread but sporadic magmatic activity continued well after breakup (80 Ma and younger) in southern Africa and Brazil (Gibson et al., 1995; CominChiaramonti et al., 2011). The most common expression of this are alkaline intrusions, which are locally numerous (e.g., kimberlite fields) but involve much smaller volumes compared with the Early Cretaceous activity.

\section{Geophysical coverage}

\subsection{Existing profiles and interpretation}

The upper crustal structure on both margins is well constrained by multichannel reflection seismic data, and this has been used for mapping the distribution of SDRs and their segmentation along the margins (e.g., Bauer et al., 2000; Franke et al., 2007; Koopmann et al., 2014a; Gladczenko et al., 1998). In contrast to the reasonable spatial coverage of seismic reflection data, wide-angle seismic lines are few, especially on the South American margin, which motivated the new studies reported below. To some extent, gaps in the seismic coverage can be compensated for by regional gravity interpretations (e.g., Blaich et al., 2009, 2011; Dragoi-Stavar and Hall, 2009; Maystrenko et al., 2013; Franke et al., 2006; Hirsch et al., 2009).

Prior to this study, five velocity profiles were available from wide-angle seismic studies and four of them are on the African margin (Fig. 1). Bauer et al. (2000) presented seismic velocity and gravity models for two seismic refraction traverses of the Namibian margin at $22-24^{\circ} \mathrm{S}$ (Fig. 1, lines 4 and 5), which show thick bodies of HVLC beneath a broad zone of SDRs (inner wedge, flat-lying flows and outer wedge). The third seismic traverse on this margin crosses the Namibian coastline near Orange River (Fig. 1, line 6) (Schinkel, 2006). The fourth traverse is located at about $30^{\circ} \mathrm{S}$ (Fig. 1, line 7) and the seismic velocity profile derived by Hirsch et al. (2009) shows a well-developed body of HVLC below SDRs. Finally, it is worth mentioning for reference that Stankiewicz et al. (2008) published a seismic velocity profile (Fig. 1, line 8) across the sheared South African margin east of the Cape Peninsula in South Africa. This seismic profile across the FAFZ shows no evidence of magmatic features at the continent-ocean boundary, but there are small HVLC bodies well inland, which Stankiewicz et al. (2008) attributed to igneous crust formed during the $180 \mathrm{Ma}$ Karoo event, but may also be interpreted as high-density metamor- phic rocks (garnet amphibolite, mafic granulite) in the continental basement (as in Norway; see Gernigon et al., 2006).

On the South American margin, Schnabel et al. (2008) identified HVLC underlying SDRs along a traverse of the Argentina margin at latitude $44^{\circ} \mathrm{S}$ (Fig. 1 line 2). They interpreted this HVLC as magmatic underplating at the Moho with intruded lower crust above.

\subsection{New profiles}

\subsubsection{Seismic velocity}

For this study we have calculated $P$-wave velocity-depth models for two previously unpublished seismic lines at the South American margin. Line BGR04-REFR02 (Fig. 1 line 3) crosses the Argentine margin at about $47^{\circ} \mathrm{S}$, and line BGR04-REFR01 (Fig. 1 line 1) is located at $35-36^{\circ} \mathrm{S}$ (Fig. 1). In addition to seven ocean-bottom hydrophones $(\mathrm{OBH})$, one three-component seismometer was deployed to collect the data (Fig. 2). An array of 20 airguns with a total volume $51.2 \mathrm{~L}$ was used as a seismic source. Refraction line 1 and line 3 had a mean shot distance of $125 \mathrm{~m}$. The seismic $P$-wave tomography models were computed using the TOMO2d refraction and reflection travel time inversion routine described by Korenaga et al. (2000). The evaluation procedure started with a very simple model consisting of the bathymetry and a 1-D velocity model to the basement as constrained by coincident seismic reflection data. For the resulting velocity model, we inverted the first arrivals which covered the sedimentary layers, as well as the crust, down to the crust-mantle boundary. Primary phases from the refracted waves were observed at all stations, whereas coverage by reflected waves from the crust-mantle boundary (PmP phases) was slightly lower. The Moho as a reflector was sampled every $2 \mathrm{~km}$ (black line in Fig. 3). Schnabel et al. (2008) tested the velocity depth ambiguity for a similar data set on the Argentine margin (line 2) which has a comparable acquisition and processing procedure as compared to lines 1 and 3. Variations of the weighting parameter had no significant influence on the depth of the Moho.

For the inversion of line 1, we used 3576 refracted travel times. A model resulting from an inversion of these crustal phases $(\mathrm{Pg})$ formed the starting model for a joint refraction/reflection inversion. The final models, shown in Fig. 3, include an inversion of the PmP phases in addition to the Pg phases. Line 1 is constrained by 2531 reflected travel times from the PmP phases and the resulting velocity model has a root-mean-square (rms) misfit for the Pg phases of $42 \mathrm{~ms}$ and for the PmP phases of $41 \mathrm{~ms}$.

For the inversion of line 3, 2448 Pg and $727 \mathrm{PmP}$ travel times were used from eight common receiver gathers. After 25 iterations the rms travel time misfit reduced to $41 \mathrm{~ms}$, with a corresponding $\chi 2$ of 0.658 . On line 3 the seaward extent of the HVLC cannot be fully constrained due to poor ray coverage between 210 and $250 \mathrm{~km}$ distance (Fig. 3b). The 
a)
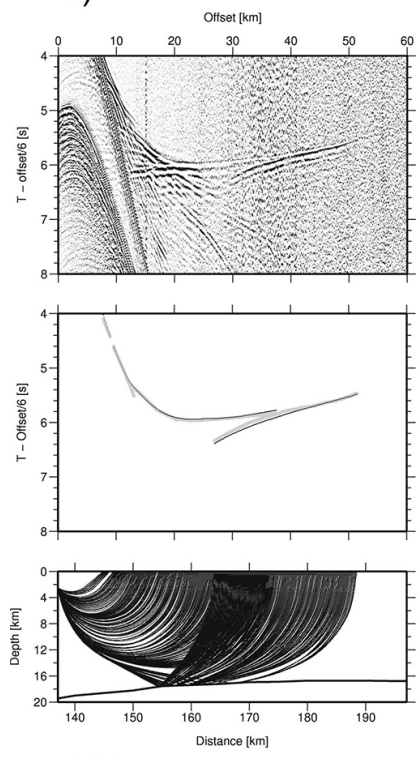

$\mathrm{OBH} 1.5$ b)
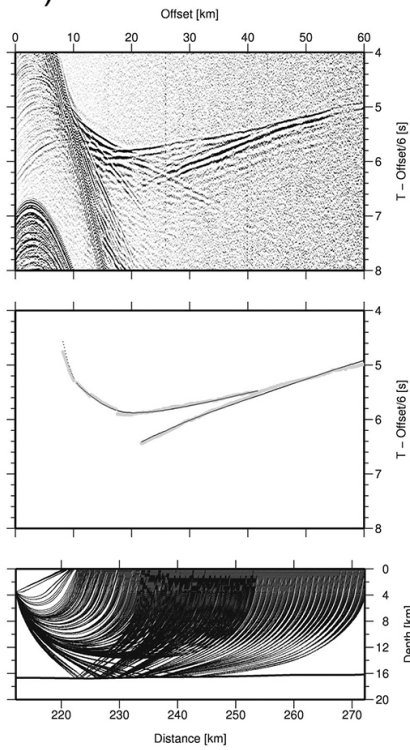

$\mathrm{OBH} 1.2$ c)
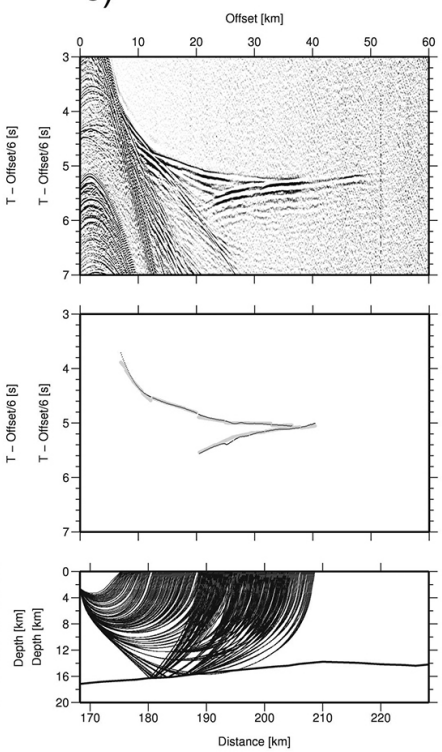

$\mathrm{OBH} 2.4$ d)
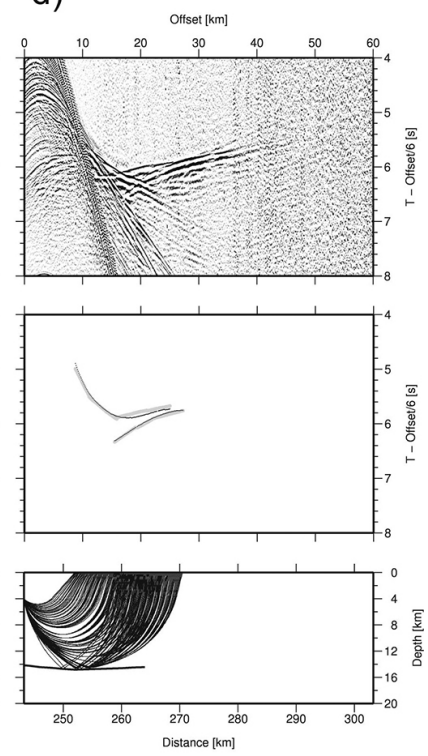

$\mathrm{OBH} 2.1$

Figure 2. Data example for ocean-bottom hydrophones (OBHs) from line 1 (a: OBH1.5; b OBH1.2) and line 3 (c: OBH2.4; d OBH2.1). The reduction velocity is $6 \mathrm{~km} \mathrm{~s}^{-1}$. Upper panels: seismic sections for OBHs. Middle panels: the middle panels represent the picked travel times as gray circles and the calculated travel times as black dots for the final model. Lower panels: the lower panels show the ray coverage for the stations.

eastern parts of both lines show distinct regions of HVLC, with velocities between 7 and maximal $7.5 \mathrm{~km} \mathrm{~s}^{-1}$ at the base of the crust (Fig. 3).

\subsubsection{Checkerboard tests and resolution}

We performed checkerboard tests to examine the resolution of the data imaging the crust-mantle boundary. The velocities of the final model were perturbed by variations of $\pm 5 \%$, resulting in a checkerboard with cells of dimension $25 \mathrm{~km} \times 9 \mathrm{~km}$ for line 1 (see Fig. 4a upper panel), and $30 \mathrm{~km} \times 12.5 \mathrm{~km}$ for line 3 (Fig. 4c). Synthetic travel times were calculated using this input model and the given source receiver geometry. We assumed an uncertainty of $50 \mathrm{~ms}$ in the identification of the travel times and inverted these data to recover the undisturbed anomaly pattern (Fig. 4a, c, lower panel). The results show that the resolution is good at shallow crustal depth. To resolve the artificial velocity perturbation in the lower crust, we conducted a second test, where we placed three different anomalies (characterized by Gaussian spikes, ellipses with $a=10 \mathrm{~km}, b=1.5 \mathrm{~km}$ ) in the lower crust (Fig. 4b, d, upper panel). The obtained recovery displayed in Fig. 4b confirms that we are also able to resolve variations in the lower crust exceeding $10 \mathrm{~km}$ horizontal and $1.5 \mathrm{~km}$ vertical dimension.
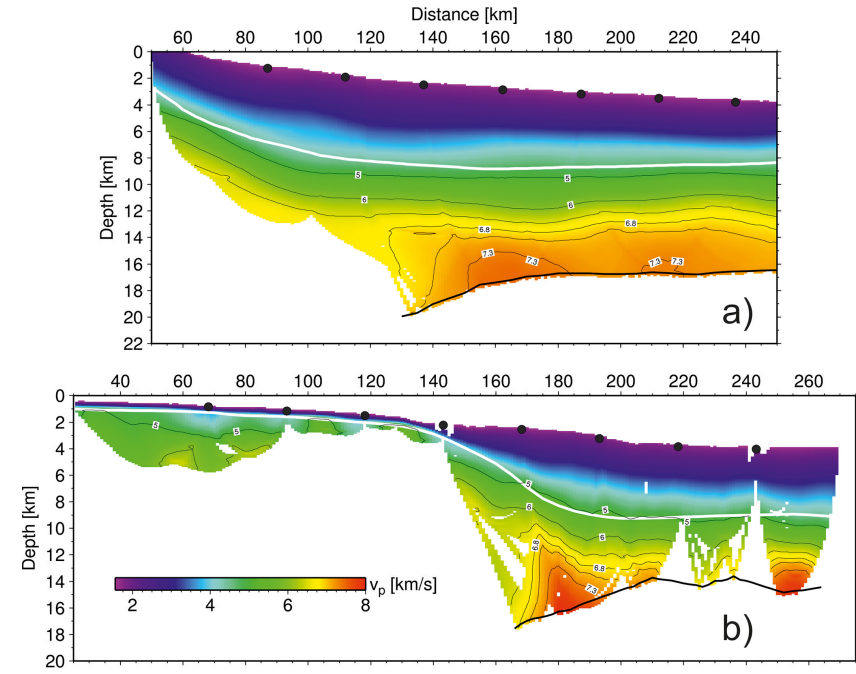

Figure 3. The resulting $P$-wave velocity models according to deep seismic refraction experiments along profile (a) line 1 and (b) line 3 of the South American margin. The location of the lines is shown in Fig. 1. The white line roughly resembles the $4.8 \mathrm{~km} \mathrm{~s}^{-1}$ isoline and marks the top of the basement, and the black line is the Moho. The basement depicts the breakup unconformity on the continental crust separating the crystalline basement from the postrift sediments and evolves eastwards into the top of the oceanic crust. Black points indicate $\mathrm{OBH}$ positions. 


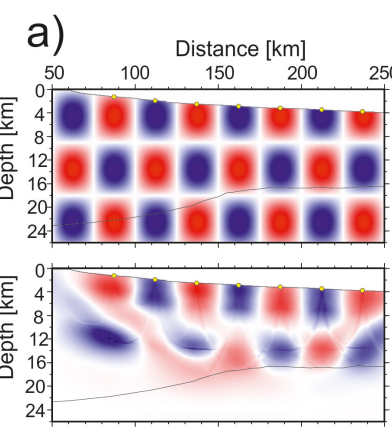

c)
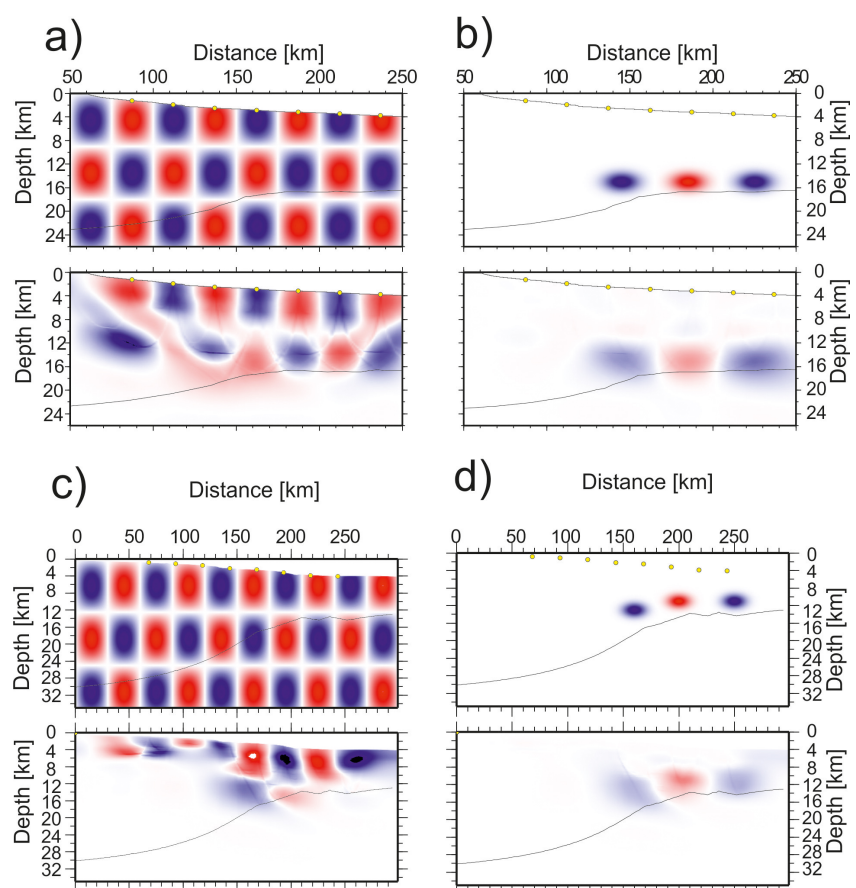

d)

Distance $[\mathrm{km}]$

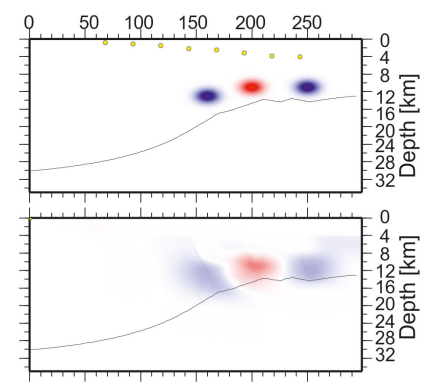

Figure 4. Checkerboard tests of line 1 and line 3. The upper panels represent the applied velocity perturbations and the lower panels the resolved velocities after eight iterations. (a) and (b) are results of line 1.(a) The upper panel shows the relative velocity perturbation of up to $5 \%$ in cells of $25 \times 9 \mathrm{~km}$. The right panels of (b) show that even small elliptical anomalies within the lower part of the crust can be resolved with the data. (c) and (d) Results of line 3. The upper panel of (c) shows the velocity perturbations of $5 \%$ in cells of $30 \times 12.5$. The panels of $(\mathbf{d})$ show the resolution test for elliptical anomalies within the lower part of the crust.

\subsubsection{Gravity models}

The seismic modeling was complemented and extended by 2-D gravity modeling (Figs. 5, 6) based on shipboard gravity data, which were processed and modeled using the software GM-SYS. For the density-depth model, structural constraints are given by the seafloor, basement and the Moho from the seismic reflection experiment. These boundaries were fixed throughout modeling. The densities of model blocks represent mean values following the velocity-density conversion law by Ludwig et al. (1970). In general, two layers were used to represent the Cenozoic and Cretaceous postrift sediments in the Argentine Basin, with densities between 2150 and $2400 \mathrm{~kg} \mathrm{~m}^{-3}$. In the area of the shallow continental shelf, the thin postrift sediments are modeled jointly as one layer. The crust is represented by three layers: upper continental, lower continental and oceanic crust. Wedges of SDRs were included in the gravity model as a single body. To set the boundaries for the HVLC we followed the $7 \mathrm{~km} \mathrm{~s}^{-1}$ isoline in the 2-D $P$-wave velocity models. From the deviation of the observed and calculated gravity for models with and without a high-density lower crustal body (see red and green lines in Figs. 5 and 6), we conclude that a high-density lower crustal body within the velocity range above $7 \mathrm{~km} \mathrm{~s}^{-1}$ determined by the tomography is necessary to fit the observed gravity values. The dimension of the HVLC bodies is verified by refraction seismics. We can observe a strong lateral gradient in the velocities to values below $7 \mathrm{~km} \mathrm{~s}^{-1}$ eastwards of the HVLC, where there is a lack of data in line 1 and 3 due to low quality. Gravity modeling confirms the extent of the HVLC within the distance range given by the tomography. A refraction seismic line across the Colorado Basin also shows that the HVLC is limited to an area close to the continent-ocean transition and gives evidence that there is no continuation of the HVLC to the west (Franke et al., 2006).

\section{Distribution and geometric analysis of the HVLC}

HVLC bodies (with $\mathrm{Vp}>7.0 \mathrm{~km} \mathrm{~s}^{-1}$ ) are identified in all deep seismic lines on the conjugate margins of the South Atlantic (Figs. 7 and 8). However, the HVLC bodies differ greatly in thickness and velocity, and the emphasis of this section is to document and interpret these differences. Useful points of reference are the Rio Grande Rise-Walvis Ridge in the north and the FAFZ in the south (Fig. 1), as well as the seafloor-spreading anomalies M4 and M0, which are mapped on both conjugate margins (Fig. 1). To define the size and seismic properties of the HVLC bodies along the traverses, we divided the velocity profiles into vertical sections with $20 \mathrm{~km}$ width and compiled for each section the thickness and the average Vp of HVLC. Due to the use of different modeling approaches for the eastern and western margin we have to differentiate between the respective uncertainties. For the western margin, the estimated uncertainty in average $\mathrm{Vp}$ estimates is probably better than $0.1 \mathrm{~km} / \mathrm{s}$, and the uncertainty in thickness is on the order of $1 \mathrm{~km}$. All relevant lines on the African margin were modeled with a forward modeling routine. Thus the uncertainties relating the eastern margin are higher.

The South American margin at the latitude of line 3 is classified as magma-poor because there are no SDRs and no records of Cretaceous igneous rocks onshore. However, the seismic velocity and gravity models do indicate small bodies of HVLC with a total estimated cross-sectional area of about $120 \mathrm{~km}^{2}$, a maximum thickness of $4.4 \mathrm{~km}$ and maximum average $\mathrm{Vp}$ of nearly $7.3 \mathrm{~km} \mathrm{~s}^{-1}$ (one segment has a local maximum of $7.6 \mathrm{~km} \mathrm{~s}^{-1}$ ). The lack of SDRs above the HVLC body calls into question whether it can be interpreted as a magmatic feature related to breakup. Farther north along the margin, on lines 2 and 1, the area of HVLC increases to 334 and $586 \mathrm{~km}^{2}$, respectively. The corresponding values for maximum thickness are 4 and $6 \mathrm{~km}$, and the average $\mathrm{Vp}$ values reach 7.4 and $7.3 \mathrm{~km} \mathrm{~s}^{-1}$, respectively.

The seismic profiles in South Africa and Namibia show much greater amounts of HVLC (Fig. 9). The southernmost 

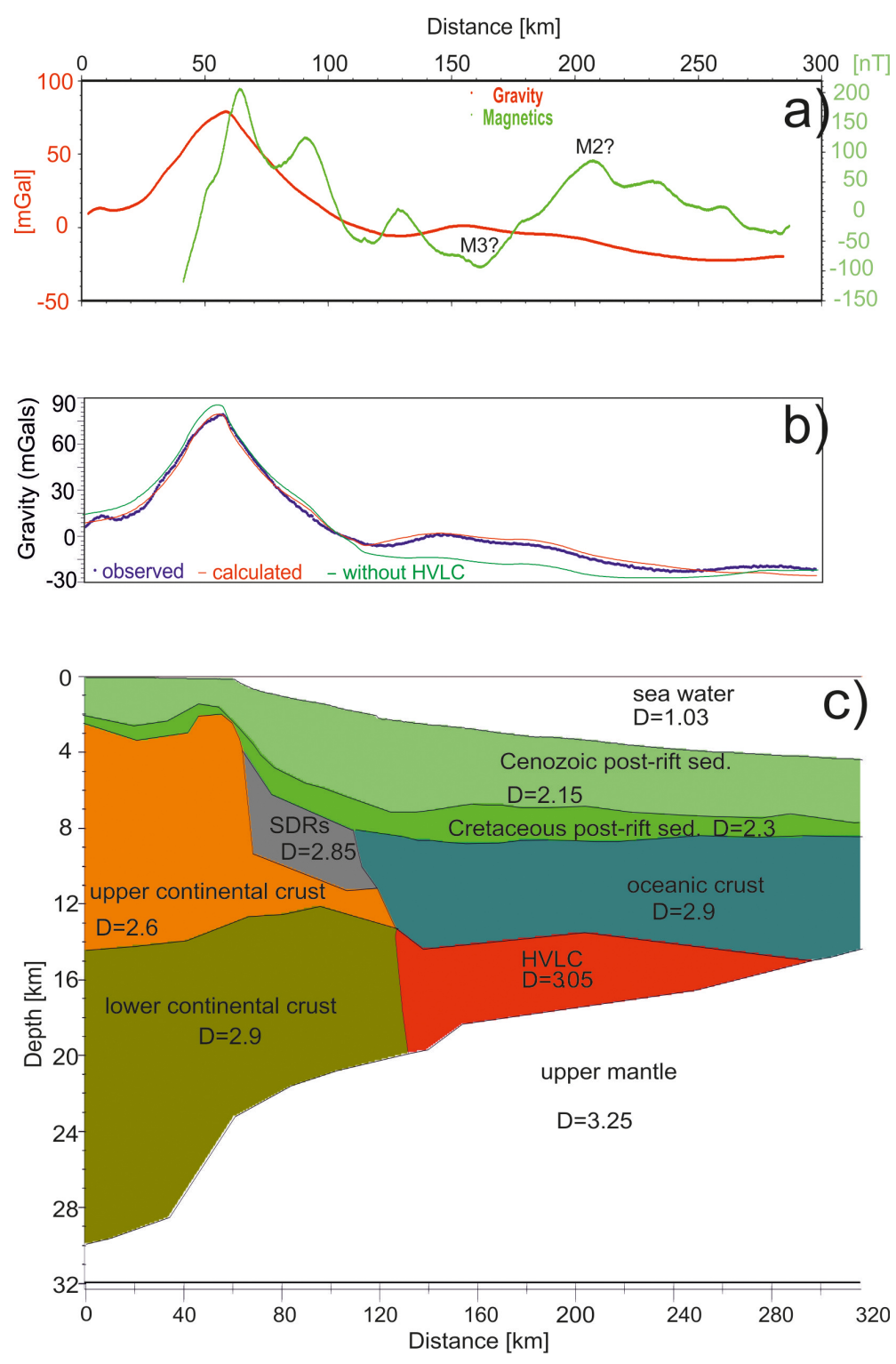

Figure 5. Two-dimensional gravity model along northernmost line 1 from the western margin as adopted from velocity modeling. (a) Observed shipborne gravimetric (red) and magnetic (green) data with tentative interpretation of magnetic anomalies M3 and M2. (b) Observed (blue) and calculated (red) gravity curves shown for the gravity model. The green line displays the curve for a gravity model without an HVLC body. (c) Result of 2-D gravity modeling showing a deep crustal transect with a gradually thinning crust-mantle boundary towards the oceanic domain. The HVLC results in thick mafic crust close to the continent-ocean transition before a typical thickness of the oceanic crust is reached at the eastern end of the line. The density values are given in $\mathrm{g} \mathrm{cm}^{-3}$. SDRs: seaward-dipping reflectors; HVLC: high-velocity lower crust.

traverse, line 7 at about $30^{\circ} \mathrm{S}$, has a cross-sectional area of HVLC of $1340 \mathrm{~km}^{2}$, a maximum thickness of about $10 \mathrm{~km}$ and highest average $\mathrm{Vp}$ of $7.4 \mathrm{~km} \mathrm{~s}^{-1}$. The next traverse to the north, at Orange River (line 6), has a well-developed HVLC with a cross-section area of about $1900 \mathrm{~km}^{2}$, maximum thickness of $12 \mathrm{~km}$ and maximum average $\mathrm{Vp}$ of $7.3 \mathrm{~km} \mathrm{~s}^{-1}$. Finally, the two northern refraction lines in Namibia (4 and 5), about $100 \mathrm{~km}$ apart and $500 \mathrm{~km}$ north of Orange River, show thick and broad bodies of HVLC.
The HVLC in line 5 (Mamba 2) has a cross-section area of $2530 \mathrm{~km}^{2}$, average $\mathrm{Vp}$ of $7.2 \mathrm{~km} \mathrm{~s}^{-1}$ and maximum thickness of $20.5 \mathrm{~km}$. The HVLC on line 4 (Mamba 1) has an even larger cross-section area of $3240 \mathrm{~km}^{2}$, maximum thickness of $18 \mathrm{~km}$ and average $\mathrm{Vp}$ reaching $7.3 \mathrm{~km} \mathrm{~s}^{-1}$. We point out that the estimated volumes of the HVLC based on 2-D sections for lines 4 and 5 are likely to be overestimated because these lines do not run perpendicular to the continental margin. We have not corrected for this effect because to do so 

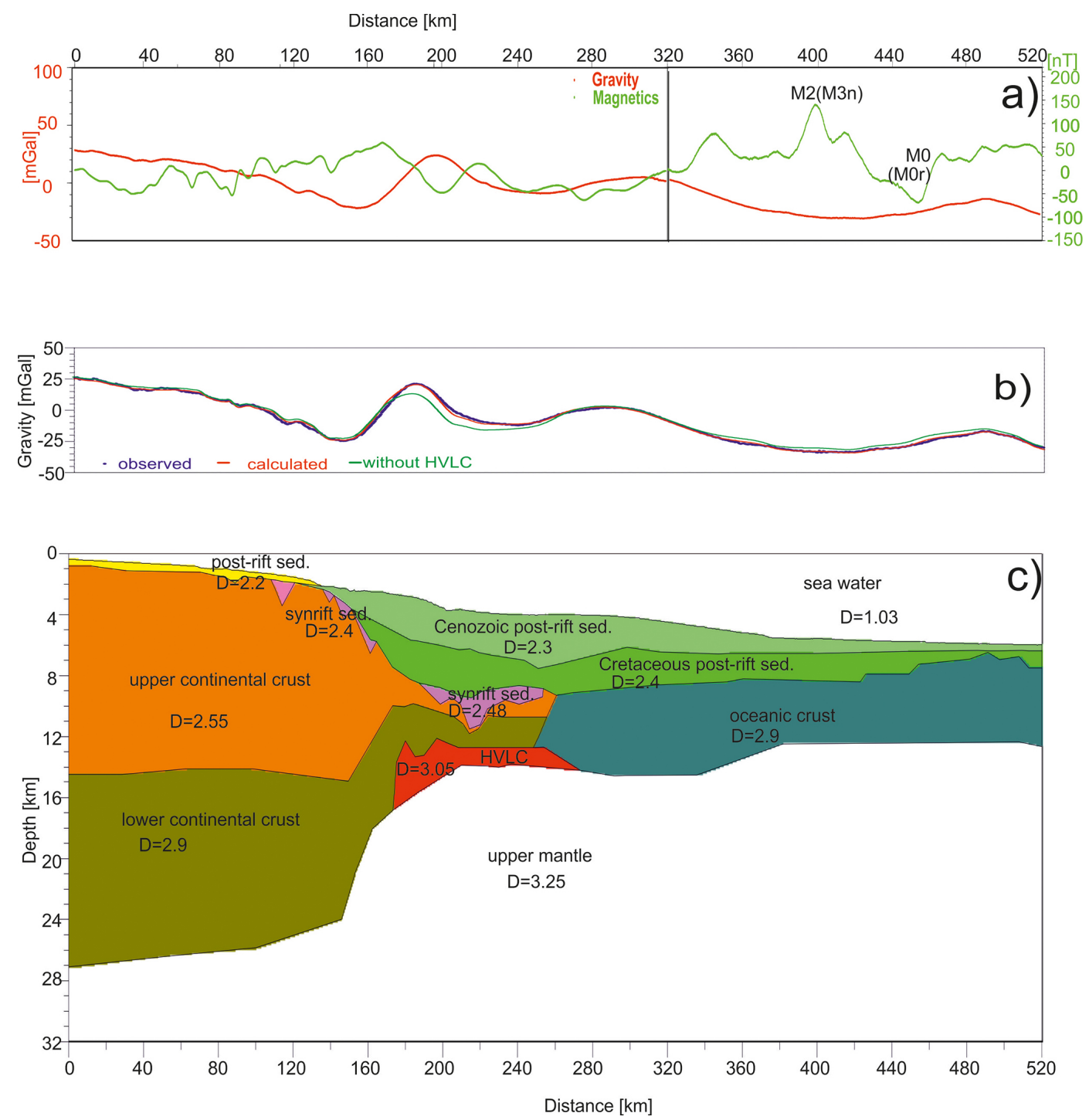

Figure 6. Two-dimensional gravity model of the southernmost line 3 from the western margin as adopted from velocity modeling. (a) Observed gravimetric (red) and magnetic (green) data with interpreted magnetic anomalies M2 and M0. (b) Observed (blue) and calculated (red) gravity curves shown for the gravity model. The green line displays the curve for a gravity model without an HVLC body. (c) Result of 2-D gravity modeling showing an abrupt thinning of the continental crust when approaching the oceanic domain. The density values are given in $\mathrm{g} \mathrm{cm}^{-3}$.

requires information about the 3-D shape of the HVLC bodies and that is not constrained.

In summary, the HVLC bodies are 2-3 times thicker and about 4 times larger in cross-sectional area on the African margin compared to the South American margin, and this contrast is maintained along the entire $\mathrm{N}-\mathrm{S}$ extent of the margins. A striking feature of the African margin profiles is a systematic increase in the size of the HVLC from south to north (Fig. 9).

\section{Discussion}

\subsection{Origin of the HVLC bodies}

HVLC bodies on volcanic rifted margins are commonly interpreted as mafic igneous crust related to rift-induced mantle melting, but many researchers have pointed out that there are other possibly explanations. These fall into two categories: (1) high-density metamorphic rocks at the base of the prerift continental crust or (2) serpentinized upper mantle.

Holbrook et al. (1992) pointed out that $P$-wave velocities greater than $7.0 \mathrm{~km} \mathrm{~s}^{-1}$ are found in seismic refraction studies of the lower continental crust. Based on extensive data 

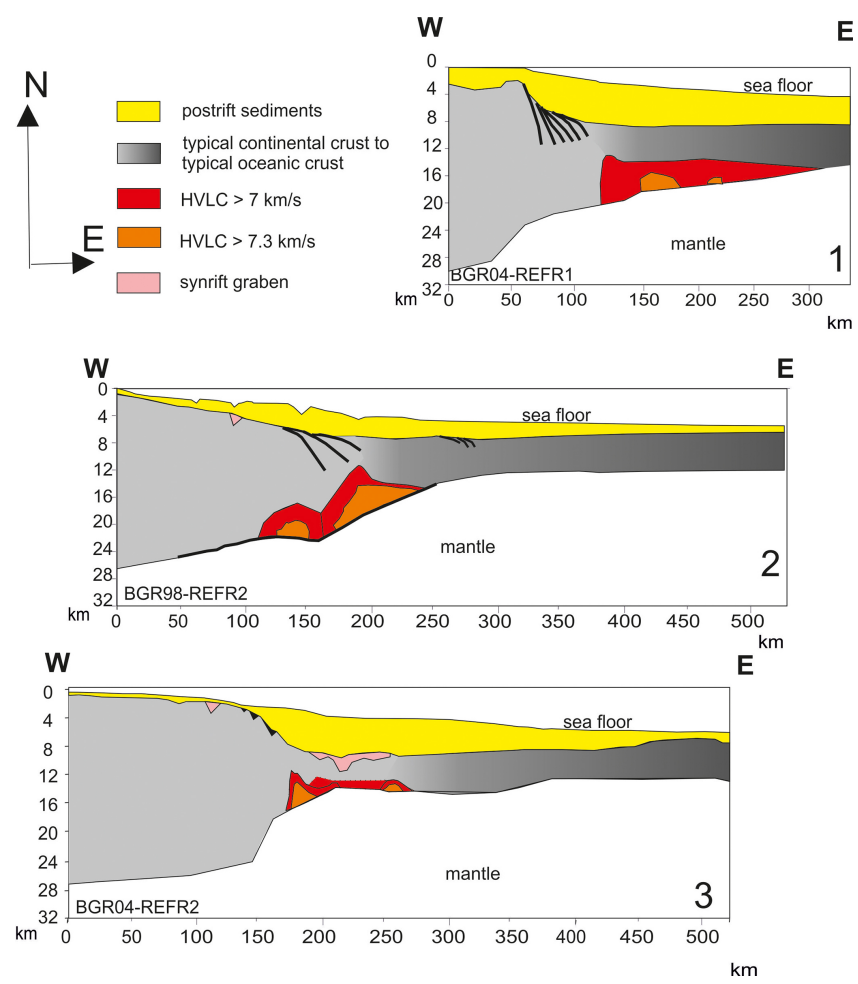

Figure 7. Interpretation of the crustal-scale lines 1-3 from north (top) to south (bottom) along the South American margin with emphasis on the HVLC. HVLC with $P$-wave velocities above $7.0 \mathrm{~km} \mathrm{~s}^{-1}$ is indicated in red; HVLC exceeding $7.3 \mathrm{~km} \mathrm{~s}^{-1}$ is shown in orange. Line 2 is modified after Schnabel et al. (2008). The shape and distribution of SDRs as interpreted from coincident seismic reflection data are indicated as black lines on line 1 and 2.

for typical crustal lithologies, such high velocities (and/or corresponding density) can be assigned to high-grade mafic crustal rocks (e.g., mafic granulites, garnet amphibolites, or mixtures of mafic and ultramafic igneous rocks. From the position of the HVLC bodies under the present coastal regions on most profiles, we can rule out a contribution from cratonic crust. The Neoproterozoic mobile belts are typically volcano-sedimentary sequences, metasediments and felsicintermediate plutonic complexes of an arc or back-arc association (Frimmel et al., 2011) and are not known or expected to contain thick sections of high-density mafic rocks in the lower crust. Where the seismic profiles are long enough to constrain lower-crustal velocities of the Damara or Gariep Belt (lines 4, 5, 6), the values do not exceed $6.8 \mathrm{~km} \mathrm{~s}^{-1}$, and the same is true for the Cape Fold Belt and NamaquaNatal Mobile Belt (line 8 in Fig. 1). Stankiewicz et al. (2008) described a zone of HVLC in the Namaqua-Natal Mobile Belt with $>7 \mathrm{~km} \mathrm{~s}^{-1}$, but interpreted this as mafic intrusions from the Karoo igneous event since seismic studies of the Namaqua-Natal Mobile Belt in other locations (e.g., Green and Durrheim, 1990; Hirsch et al., 2009) did not identify high velocities in the lower crust. Therefore, there is no reason to

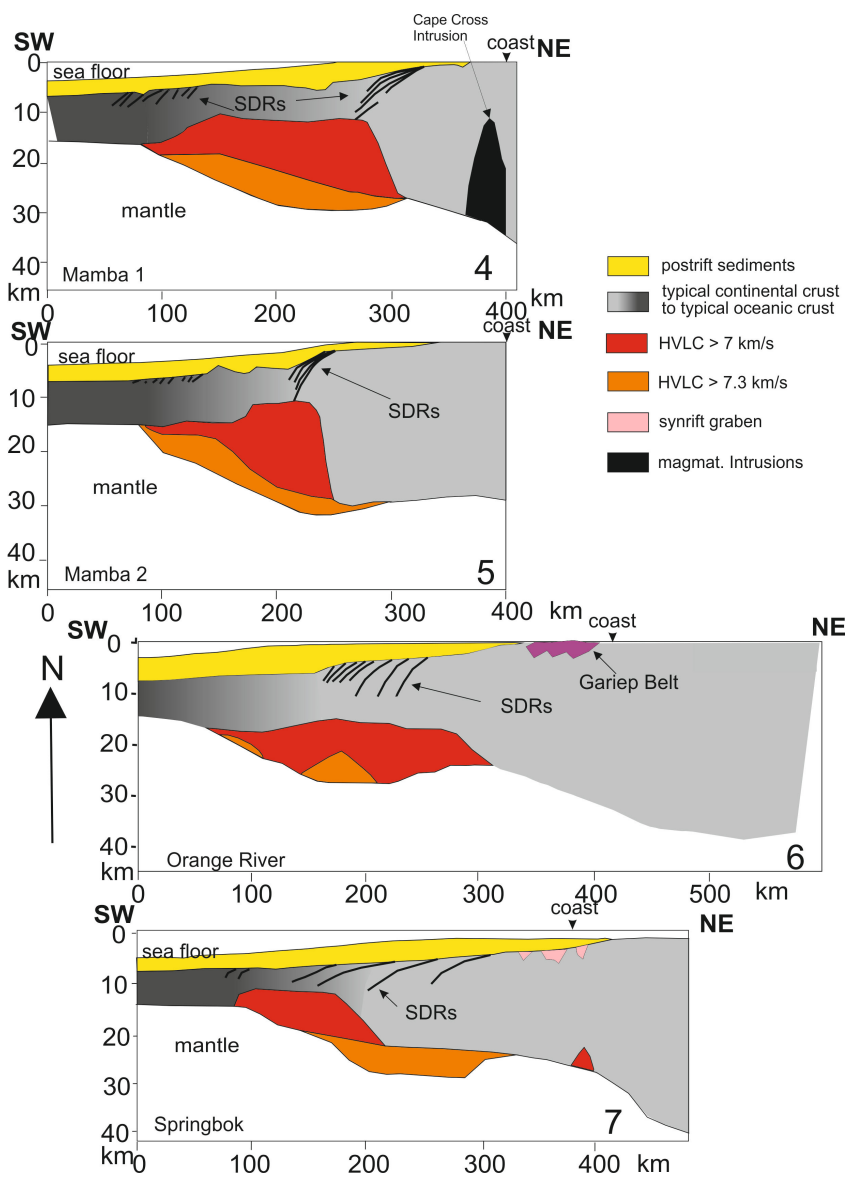

Figure 8. Interpretation of the crustal-scale lines 4-7 from north (top) to south (bottom) along the South African margin with emphasis on the HVLC. HVLC with $P$-wave velocities above $7.0 \mathrm{~km} \mathrm{~s}^{-1}$ is indicated in red, HVLC exceeding $7.3 \mathrm{~km} \mathrm{~s}^{-1}$ is shown in orange. Line 4 (Mamba 1) and line 5 (Mamba 2) are modified after Bauer et al. (2000), line 6 (Orange River mouth) is modified after Schinkel (2006) and line 7 (Springbok) is modified after Hirsch et al. (2009). The shape and distribution of SDRs as interpreted from coincident seismic reflection data are indicated as black lines. Same scale as in Fig. 7.

expect that pre-rift crustal rocks contribute significantly to the HVLC bodies described on the South Atlantic margins.

The next possible explanation is serpentinization of mantle peridotites. This process is known to occur when oceanic crust is thinned to a thickness of $5 \mathrm{~km}$ or less (Mjelde et al., 2002), where brittle and semi-brittle faults provide pathways for downward migration of seawater. We consider this concept to be unlikely in the South Atlantic for the following reasons. First, if serpentinization beneath the thinned crust took place, it must have occurred before the emplacement of the SDRs, which would be expected to seal deep-reaching faults. Furthermore, the HVLC bodies along the northernmost lines 1,4 and 5 developed maximum thickness at the continentocean transition and extend from there for a considerable distance under oceanic crust, and therefore their formation at 
least partly postdates the emplacement of the SDRs. Third, the vertical extent of the HVLC bodies, especially on the African margin, is greater than $10 \mathrm{~km}$, far exceeding values suggested for serpentinized mantle in other studies. We find it difficult to envision a process that could produce such thick serpentinized zones. Finally, the serpentinization model offers no explanation for the systematic north-south variations in HVLC distribution that is observed and (see below) is consistent with an origin from mantle-derived melts.

The conjugate margins on the South Atlantic were classified as volcanic because of the emplacement of the SDRs. Due to the close spatial correlation of SDRs and HVLC, a magmatic origin for the latter seems likely, with underplating or mafic intrusions as the most probable reasons for the anomalous velocity layer. In its original meaning, underplating described the accumulation of magmatic material at the base of the crust. Nowadays the term "underplating" combines both processes, i.e., mafic intrusions and underplating (Thybo and Artemieva, 2013; Mjelde et al., 2002). Bauer et al. (2000) favor sensu stricto accreted igneous material over intrusions as an explanation for the HVLC in line 4 and 5. Intrusions related to the Cretaceous Cape Cross complex with velocities of $6.9-7.2 \mathrm{~km} \mathrm{~s}^{-1}$ fail to explain the part of the HVLC with velocities above $7.2 \mathrm{~km} \mathrm{~s}^{-1}$ (displayed in orange in Fig. 8) and differ in shape from the HVLC bodies. It is important to note that the $P$-wave velocities in HVLC bodies on the northern margin segments are considerably higher than the value of $7.2 \mathrm{~km} \mathrm{~s}^{-1}$ which is typical for ocean layer 3, i.e., gabbro of MORB (mid ocean ridge basalt) composition. It has long been recognized (e.g., Keleman and Holbrook, 1995) that the higher Vp velocities of HVLC can be explained by magmas richer in $\mathrm{Mg}$ than MORB, which are the consequence of melting at anomalously high potential temperature. Trumbull et al. (2002) suggested from petrophysical models that the HVLC intrusions on profiles 4 and 5 have 14 to $18 \mathrm{wt}$ \% $\mathrm{MgO}$, consistent with melting at 150 to $200^{\circ} \mathrm{C}$ excess temperature compared with average MORBs. Further, a sharp vertical velocity gradient above the HVLC in line 1 may argue for underplated material against small-scale intruded crust.

The HVLC along central lines 2, 6 and 7 extends over the total width of the SDRs. Previously, the HVLC was interpreted as a combination of magmatic underplating and heavily intruded crust (Schnabel et al., 2008; Hirsch et al., 2009). A low-velocity gradient above the HVLC on line 2 suggests intruded continental crust above the HVLC. Densities exceeding normal crustal values argue for intruded continental crust above the HVLC in the central lines 2, 6 and 7 (Schinkel, 2006; Hirsch et al., 2009; Schnabel et al., 2008), which implies the HVLC being intruded crust.

If the HVLC of line 3 is magmatic material, it may be interpreted as an intrusion, which has not reached the surface to form SDRs. The small thickness of the HVLC makes magmatic underplating unlikely for this section. This does not necessarily mean the HVLC is composed of serpentinized mantle. The HVLC occurs together with an extremely thin continental crust and with a synrift basin above the HVLC, which may have eased water entry to serpentinize mantle peridotites. Since serpentinization is a gradual process with no clear interface (Mjelde et al., 2002), the presence of Moho reflections at the base of the HVLC argues against the model of serpentinized peridotites and supports, together with a sharp vertical and lateral velocity gradient surrounding the HVLC, the hypothesis of an intrusive body. Based solely on seismic observations we cannot clearly decide on one hypothesis - magmatic intrusions or serpentinization.

\subsection{Relationship of HVLC and SDR sequences}

All margin profiles except line 3 from southern Argentina show well-developed SDR wedges close to the HVLC. Previous studies have demonstrated a common pattern of SDR sequences with distinctive "facies" consisting of an inner (landward) SDR wedge interpreted as subaerial lava flows, which is followed by a zone of flat SDRs and commonly an outer wedge that presumably formed in a submarine setting (Planke and Eldholm, 1994). The generation of the SDRs is assumed to be restricted to the breakup process and lies close to the continent-ocean boundary (Mutter, 1985; Hinz, 1981). Astonishingly, there is a distinct seaward shift of the HVLC relative to the SDRs. While in the south the HVLC is situated below the SDRs, towards the north the HVLC formed seaward of the SDRs. The contrast in their distribution across the conjugate Atlantic margins, nearly symmetrically SDRs (Koopmann et al., 2014b) against asymmetrically HVLC, questions a simple intrusive vs. extrusive relationship between them. The formation of the HVLC bodies seems to be more complex than merely a breakup-related feature. This is indicated by the 2-fold HVLC as found along line 2, which could be explained by a formation during different stages of the rifting and breakup. From the position of HVLC bodies relative to the SDRs, we try to infer the approximate timing of the HVLC emplacement.

The HVLC of the southernmost line 3 was found in continental crust in an SDR-free, magma-limited environment. This challenges the intrinsic relationship between SDRs and HVLC. On the central lines where SDRs and HVLC are well developed (2, 6 and 7), the vertical coincidence of SDRs and HVLC (Hinz et al., 1999; Blaich et al., 2009, 2011) suggests that the HVLC bodies are of synrift character. This resembles the classical architecture of volcanic rifted margins. The heavily intruded crust under the SDRs of the central lines 2, 6 and 7 (Schnabel et al., 2008) may have acted as conduits providing magma for the thick volcanic flows imaged as SDRs (line 2 and line 7). The HVLC of the northernmost lines 1, 4 and 5 is located mainly seaward of the inner SDRs. The HVLC bodies show maximum thickness beneath the inner SDR wedges and thin slowly with increasing plate separation. This implies that the formation of the HVLC initiated at 


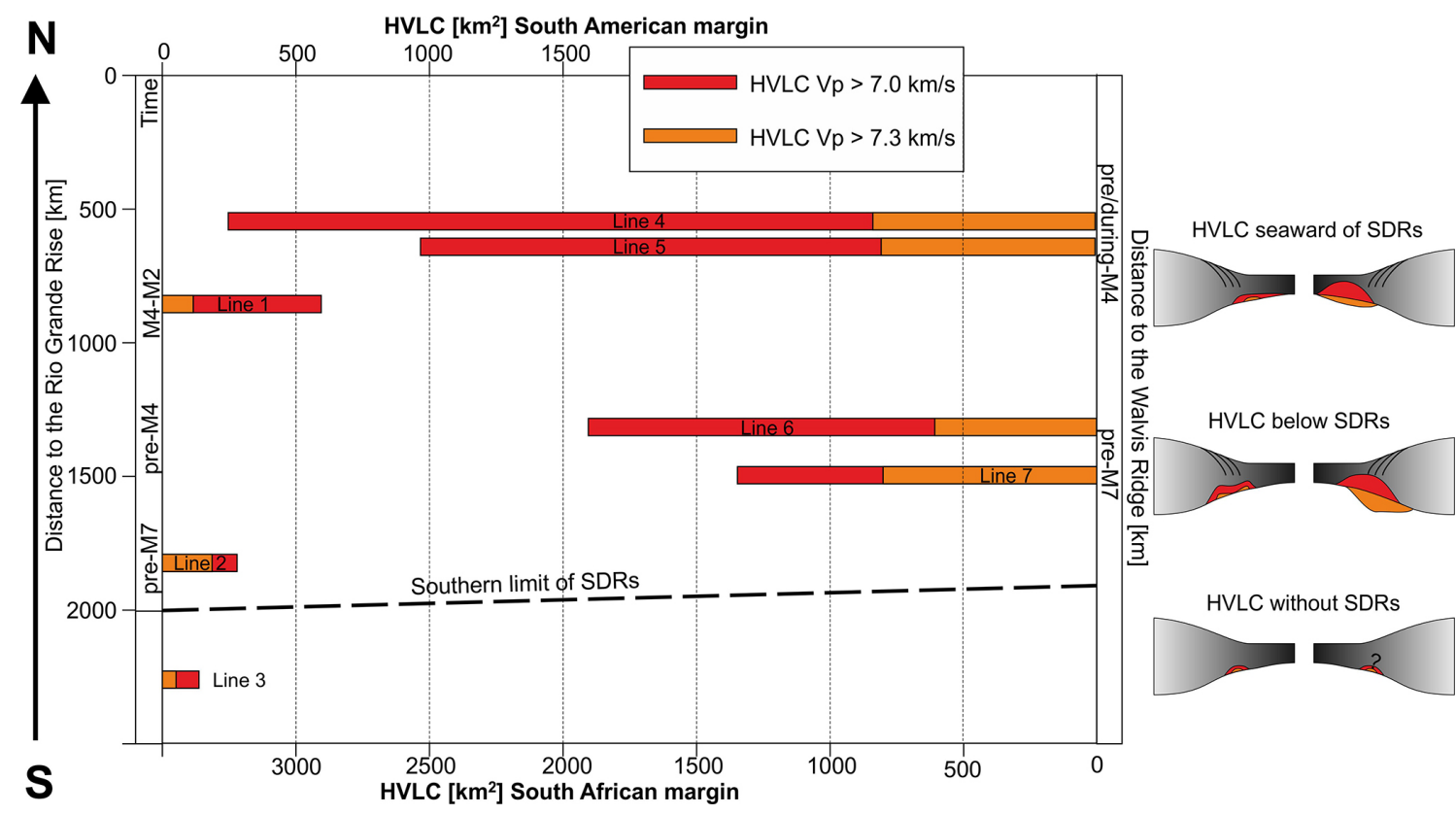

Figure 9. Comparative N-S volumes of HVLC in the South Atlantic along the crustal transects. HVLC on the South American margin is shown to the left and aligned according to the distance from the Rio Grande Rise (top). HVLC on the South African margins is shown to the right and aligned according to the distance from the Walvis Ridge (top). The timing of the emplacement of HVLC is indicated with respect to magnetic chrons M7, M4, and M2. Southern limit of the SDRs corresponds to the Colorado-Cape transfer zone as indicated in Fig. 1. The diagrams to the right show the respective spatial relation of the HVLC to the SDRs at the relative margin position.

breakup marked by the SDR inner wedge but continued into the phase of margin subsidence and steady seafloor spreading as indicated by magnetic anomaly M4 (130 Ma) at the seaward end of the HVLC.

We do not have the advantage of densely spaced OBS stations as, for example, Mjelde et al. (2007), but we consider the inner SDR sequences as being emplaced predominantly over extended continental crust (Hinz, 1981). Planke et al. (2000) argued that the arcuate, diverging reflection pattern in the inner SDRs are related to more numerous and thicker lava flows towards the rift axis where the largest accommodation space was created. The southernmost HVLC on the western South Atlantic margin likely lies below stretched continental crust, but there is no corresponding SDR sequence. We consider this HVLC to represent intrusions into stretched continental crust, where magmas extrusion failed to take place or was so minor as to not show up seismically. The HVLC intrusions on this profile may have occurred before breakup and seafloor spreading. In the central portion of both conjugate margins, the HVLC likely represents a combination of lower crustal intrusions beneath the inner SDR sequences and later underplating that extends farther seaward. The proportion of magmatic underplating vs. crustal intrusion increases to the north, and in the northern margin segment underplating predominates. There, a major part of the HVLC was emplaced in the oceanic domain, leading to considerably thickened oceanic crust which is clearly of post-breakup age.
The HVLC in the central segment of the margins (Fig. 9) formed coincident with magnetic anomalies M11/M9 (about 136 to $133 \mathrm{Ma}$ ), but before M7. In the north, the HVLC formation postponed anomaly M7 but continued until anomaly M4, at ca. $130 \mathrm{Ma}$. Thus, the seaward-shifting HVLC bodies suggest that the HVLC formation followed the northwardmigrating South Atlantic rift.

\subsection{Asymmetry of magmatism and implications for the breakup process}

Our study shows a 4-fold difference in the cross-sectional area of the HVLC between the South American and African margins (Fig. 9). A new assessment of SDR distribution and area by Koopmann et al. (2014b) reveals a more symmetric distribution, with only $50 \%$ difference in area $\left(0.2 \times 10^{3}\right.$ for South America vs. $0.3 \times 10^{3} \mathrm{~km}^{2}$ for Africa), which is insignificant considering the uncertainties. Interestingly, both the HVLC and SDR distributions are completely at odds with the onshore record in the Paraná-Etendeka Large Igneous Province, where the magma volumes in South America are on the order of 10 times greater than on the African side. The Paraná volcanic units cover at least $1.2 \times 10^{6} \mathrm{~km}^{2}$ (Peate et al., 1992). The equivalent units on the African margin cover $0.08 \times 10^{6} \mathrm{~km}^{2}$ (Erlank, 1984), to which we may add an equivalent area covered by basaltic feeder dikes where lavas are eroded (Trumbull et al., 2004, 2007). Taking maximum thickness values for the Paraná-Etendeka sequences 

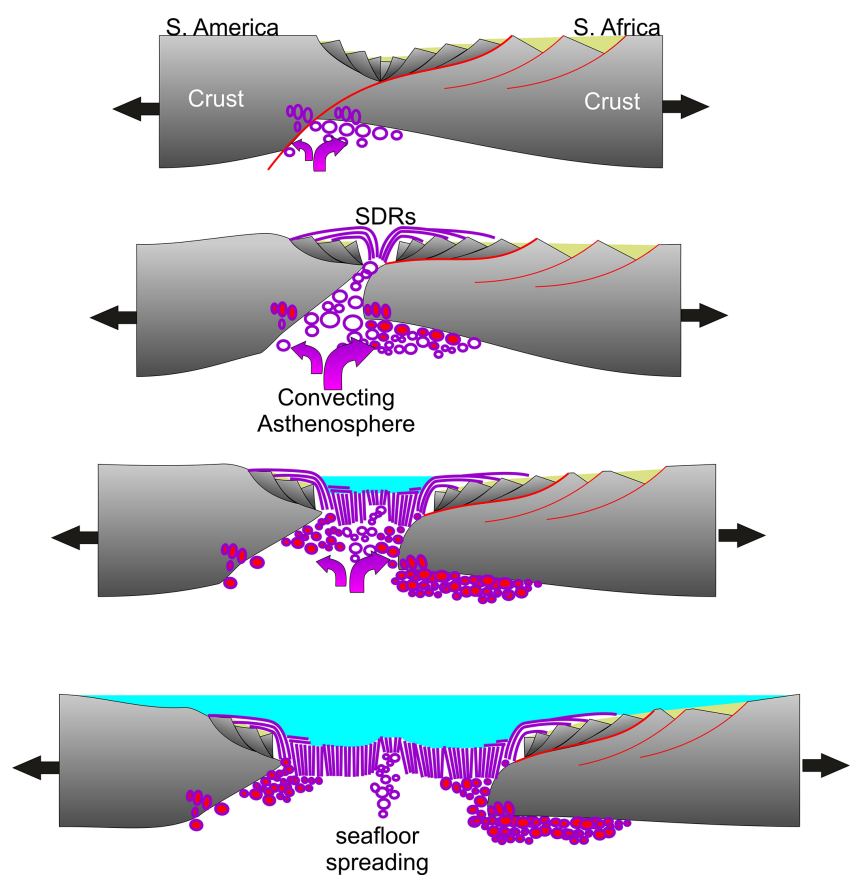

Figure 10. Conceptual model for the asymmetric emplacement of the HVLC in a simple-shear rift setting. According to the lithospheric model, extension is accomplished by displacement along a major detachment, resulting in nonuniform extension of crust and mantle lithosphere. Melts will intrude into the continental lower crust and fill the resulting space below. Continued extension and subsidence results in increasing similarities of upper crustal architecture on both margins but the major asymmetry in HVLC will be preserved.

into account $(1.7 \mathrm{~km}$ in Brazil vs. $0.9 \mathrm{~km}$ in Namibia from Peate et al., 1992) yields volumes of $1.4 \times 10^{6} \mathrm{~km}^{3}$ and $0.14 \times 10^{6} \mathrm{~km}^{3}$ for South America and Africa, respectively, which are likely to be minimum estimates given the advanced state of erosion.

This brings up two important questions: how did the strong asymmetry of magmatism develop during rifting and breakup in the South Atlantic, and why is there such a difference in the sense of asymmetry from the offshore and onshore evidence? One point to consider is that the Paraná-Etendeka Large Igneous Province is a feature of the northern end of the margins only and not necessarily related to the Atlantic rifting which started in a magma-poor setting in the south. Franke (2013) points out that there was already a wellestablished seafloor-spreading system in the southern South Atlantic during the peak of Paraná-Etendeka volcanism onshore (130 \pm 2 Ma after Peate, 1997). Nevertheless, the contrast in asymmetry of onshore volcanic rocks and HVLC is a general feature of the margins and must be explained in the context of the breakup process. One explanation for the smaller volume of volcanic rocks on the Namibian margin relative to South America could be a greater extent of postrift uplift and erosion, but fission-track and denudation studies on both margins do not support this (Gallagher and Hawkesworth, 1994; Gallagher et al., 1994). We suggest that South America possibly offered more favorable structures for magma ascent and extrusion than South Africa.

Potentially, the greater HVLC volumes on the African margin could reflect a misinterpretation of the HVLC as igneous crust. Arguments for an igneous origin of HVLC were given above, but we cannot claim that the HVLC bodies consist entirely of igneous material, especially for their landward border under inner SDR wedges. It seems, however, both unlikely and ad hoc to suggest that the proportion of continental material in the African HVLC bodies should be many times greater than on the conjugate margin. Also, if we suppose that less than half of the African HVLC represents mafic intrusions, their seismic velocity would need to be much greater than $7.5 \mathrm{~km} \mathrm{~s}^{-1}$ to explain the observed average Vp values of the HVLC bodies. Thus, it seems safe to assume that much of the HVLC observed along the South Atlantic margins represents magmatic material of mantle origin. However, there is little good evidence regarding the timing of HVLC-forming intrusions. A breakup-related context for the initial formation is suggested by the coincidence of the landward end of HVLC with the inner SDR wedge on most of the profiles. However, as pointed out above, the HVLC bodies on the northern margin profiles extend for $100-150 \mathrm{~km}$ seaward of the inner SDRs, and as far as spreading anomaly M4. It might be speculated that part of the larger volumes of HVLC on the African margin are related to a longer duration of magma generation and accumulation. Indeed, it is clear from onshore geology that there were postrift magmatic events in the Late Cretaceous (90$70 \mathrm{My}$ ), late Eocene/early Oligocene ( 40 Ma) and Miocene (Bailey, 1992, 1993; de Wit, 2007) in southern Africa. The surface expressions of postrift magmatism must have an intrusive equivalent at depth that may contribute to the present volume of HVLC. This would only hold for the landward part of the HVLC. Postrift magmatism as a consequence of uplift cannot be made responsible for the seaward part of the HVLC. Further, it fails to explain the systematic decrease in the cross-sectional area of the HVLC to the south.

Despite many uncertainties regarding how and when the HVLC bodies formed, it is difficult to avoid the conclusion that much of their volume formed during and slightly after continental breakup, and therefore the reason for their asymmetric distribution should relate to the breakup process itself. Asymmetric rifting with a simple-shear component of stretching offers a mechanism to explain the differences in the HVLC distribution and was earlier proposed by Blaich et al. (2011) from analysis of structures across the South Atlantic margins.

Latest rift-related sedimentary basins are confined to the eastern margin, where the Orange, Luderitz and Walvis basins indicate regions of major crustal extension and thinning, in line with the breakup direction. In contrast, the major sedimentary rift basins on the South American margin - the 
Colorado, the Salado and the San Jorge basins - are oriented perpendicular to the rift axis, which negates a symmetric extension and support the simple-shear mode of extension as already suggested by Blaich et al. (2011) and Koopmann et al. (2014b).

According to the simple-shear model, rifting is accomplished by displacement along a major detachment, resulting in nonuniform extension of the lithosphere (Fig. 10). The initial stretching process effects an asymmetrically stretched crust. The lower crust and the space below is filled by the rising melt, producing asymmetrically distributed HVLC. Figure 10 illustrates the different stages of the breakup process.

\section{Conclusions}

Two new refraction seismic models complemented by gravity models fill a gap in the data coverage on the Argentine margin and prove the existence of high-velocity lower crust (HVLC; Vp > 7.0). Combined with the models from several publications, a compilation of seven transects allows for a comparative analysis of the deep crustal structures and physical properties along the conjugate margins of the South Atlantic. All but one of them (off southernmost Argentina) show a close spatial correlation of the HVLC with the SDR sequences in the upper crust, suggesting they are magmatic features. We cannot totally rule out the possibility that the landwards parts represent metamorphic rocks like eclogites, especially for line 3, but we think that serpentinization is unlikely, since it fails to explain the systematic HVLC variations. A close spatial relationship of the HVLC to the SDRs and to flood basalts and dike swarms onshore, which were used to classify this margin as volcanic, suggests a magmatic origin for the central and northern lines. This means that underplating and intrusions of mantle-derived magmas in different combinations are the most probable origins for the HVLC bodies.

Three seismic lines on the South American margin cover the change from a magma-poor margin (lacking SDRs and magmatism) in the south to a well-developed volcanic rifted margin off Uruguay in the north and were compared with four transects across the South African margin.

In addition to the volume and the shape, the relative position of the HVLC with regard to the SDR sequences varies in a systematic way from south to north. The southernmost small HVLC formed without associated SDRs. In the central sections, the HVLC underlies the inner SDR wedges. However, the northernmost HVLC are located seaward of the inner SDRs. The northern profiles off Uruguay and Namibia show HVLC extending seaward as far as spreading anomaly M4 (130 Ma).

From the seaward-migrating position of the HVLC with regard to the inner SDR wedges, we infer the formation of the HVLC during different stages of the rifting and breakup process. If of magmatic origin, the HVLC in the magma-starved segment was likely formed before breakup. The HVLC in central part of the margins was emplaced contemporaneously with the SDRs, i.e., synrift. However, in the northernmost margin segment, the formation of the HVLC started after the emplacement of the SDRs. Thus, a causal relationship between SDRs and HVLC is questioned. The northern HVLC may have formed at the end of the breakup process and continued until the earliest seafloor spreading.

Concerning the distribution of the HVLC, we observe an increase in cross-sectional area on the conjugate margins from south to north. Evident is an asymmetry in the crosssectional area across the margins. The South African margin reveals HVLC about 4 times larger and 2-3 times thicker than the South American margin, which stands in contrast to the onshore Paraná-Etendeka flood basalt province, which shows the opposite sense of asymmetry. We attribute this asymmetry of HVLC to rifting in the simple-shear mode. There may be some analogies to the volcanic margin in the North Atlantic, where asymmetric HVLC structures were observed in the conjugate East Greenland/Hatton Bank data.

Acknowledgements. We wish to thank the reviewers for comments and suggestions which improved the manuscript. Funding by the Deutsche Forschungsgemeinschaft (German Research Foundation) within the priority program SPP1375 SAMPLE (South Atlantic Margin Processes and Links with onshore Evolution) for projects FR 2119-2-2 (K. Becker) and NE 1193-1-1 (H. Koopmann) is greatly acknowledged.

Edited by: J. C. Afonso

\section{References}

Austin, J. A. and Uchupi, E.: Continental-oceanic crustal transition off Southwest Africa, AAPG Bulletin, 66, 1328-1347, 1982.

Bailey, D. K.: Episodic alkaline igneous activity across Africa: implications for the causes of continental break-up, Geological Society, London, Special Publications, 68, 91-98, 1992.

Bailey, D. K.: Petrogenetic implications of the timing of alkaline, carbonatite, and kimberlite igneous activity in Africa, S. Afr. J. Geol., 96, 67-74, 1993.

Bauer, K., Neben, S., Schreckenberger, B., Emmermann, R., Hinz, K., Fechner, N., Gohl, K., Schulze, A., Trumbull, R. B., and Weber, K.: Deep structure of the Namibia continental margin as derived from integrated geophysical studies, J. Geophys. Res., 105, 25829-25853, 2000.

Becker, K., Franke, D., Schnabel, M., Schreckenberger, B., Heyde, I., and Krawczyk, C. M.: The crustal structure of the southern Argentine margin, Geophys. J. Int., 189, 1483-1504, 2012.

Blaich, O., A., Faleide, J. I., Tsikalas, F., Franke, D., and León, E.: Crustal-scale architecture and segmentation of the Argentine margin and its conjugate off South Africa, Geophys. J. Int., 178, 85-105, 2009.

Blaich, O. A., Faleide, J. I., and Tsikalas, F.: Crustal breakup and continent-ocean transition at South Atlantic conjugate margins, J. Geophys. Res., 116, B01402, doi:10.1029/2010jb007686, 2011. 
Comin-Chiaramonti, P., De Min, A., Girardi, V. A. V., and Ruberti, E.: Post-Paleozoic magmatism in Angola and Namibia: a review, Geol. Soc. Am. Spec. Papers, 478, 223-247, 2011.

Contrucci, I., Matias, L., Moulin, M., Geli, L., Klingelhofer, F., Nouze, H., Aslanian, D., Olivet, J.-L., Rehault, J.-P., and Sibuet, J.-C.: Deep structure of the West African continental margin (Congo, Zaïre, Angola), between $5^{\circ} \mathrm{S}$ and $8^{\circ} \mathrm{S}$, from reflection/refraction seismics and gravity data, Geophys. J. Int., 158, 529-553, 2004.

de Wit, M.: The Kalahari Epeirogeny and climate change: differentiating cause and effect from core to space, S. Afr. J. Geol., 110, 367-392, 2007.

Dragoi-Stavar, D. and Hall, S.: Gravity modeling of the oceancontinent transition along the South Atlantic margins, J. Geophys. Res., 114, B09401, doi:10.1029/2008jb006014, 2009.

Erlank, A. J.: Petrogenesis of the Volcanic Rocks of the Karoo Province: Presenting Results of the South African Geodynamics Project on the Karoo Volcanics, Geol. Soc. South Africa, 13, 1984.

Ewart, A., Milner, S. C., Armstrong, R. A., and Duncan, A. R.: Etendeka Volcanism of the Goboboseb Mountains and Messum Igneous Complex, Namibia. Part II: Voluminous Quartz Latite Volcanism of the Awahab Magma System, J. Petrol., 39, 227253, 1998.

Farnetani, C. G., Richards, M. A., and Ghiorso, M. S.: Petrological models of magma evolution and deep crustal structure beneath hotspots and flood basalt provinces, Earth Planet. Sci. Lett., 143, 81-94, 1996.

Fernàndez, M., Afonso, J. C., and Ranalli, G.: The deep lithospheric structure of the Namibian volcanic margin, Tectonophysics, 481, 68-81, 2010.

Franke, D.: Rifting, lithosphere breakup and volcanism: Comparison of magma-poor and volcanic rifted margins, Mar. Petrol. Geol., 43, 63-87, 2013.

Franke, D., Neben, S., Schreckenberger, B., Schulze, A., Stiller, M., and Krawczyk, C. M.: Crustal structure across the Colorado Basin, offshore Argentina, Geophys. J. Int., 165, 850-864, 2006.

Franke, D., Neben, S., Ladage, S., Schreckenberger, B., and Hinz, K.: Margin segmentation and volcano-tectonic architecture along the volcanic margin off Argentina/Uruguay, South Atlantic, Mar. Geol., 244, 46-67, 2007.

Franke, D., Ladage, S., Schnabel, M., Schreckenberger, B., Reichert, C., Hinz, K., Paterlini, M., de Abelleyra, J., and Siciliano, M.: Birth of a volcanic margin off Argentina, South Atlantic, Geochem. Geophys. Geosyst., 11, 2, doi:10.1029/2009GC002715, 2010.

Frimmel, H. E., Basei, M. S., and Gaucher, C.: Neoproterozoic geodynamic evolution of SW-Gondwana: a southern African perspective, Int. J. Earth Sci., 100, 323-354, 2011.

Furlong, K. P. and Fountain, D. M.: Continental Crustal Underplating: Thermal Considerations And Seismic-Petrologic Consequences, J. Geophys. Res., 91, 8285-8294, 1986.

Gallagher, K. and Hawkesworth, C.: Mantle plumes, continental magmatism and asymmetry in the South Atlantic, Earth Planet. Sci. Lett., 123, 105-117, 1994.

Gallagher, K., Hawkesworth, C. J., and Mantovani, M. S. M.: The denudation history of the onshore continental margin of SE Brazil inferred from apatite fission track data, J. Geophys. Res., 99, 18117-18145, 11994.
Gernigon, L., Ringenbach, J.-C., Planke, S., and Le Gall, B.: Deep structures and breakup along volcanic rifted margins: insights from integrated studies along the outer Vøring Basin (Norway), Mar. Petrol. Geol., 21, 363-372, 2004.

Gernigon, L., Lucazeau, F., Brigaud, F., Ringenbach, J.-C., Planke, S., and Le Gall, B.: A moderate melting model for the Voring margin (Norway) based on structural observations and a thermokinematical modelling: Implication for the meaning of the lower crustal bodies, Tectonophysics, 412, 255-278, 2006.

Gibson, S. A., Thompson, R. N., Leonardos, O. H., Dickin, A. P., and Mitchell, J. G.: The Late Cretaceous Impact of the Trindade Mantle Plume: Evidence from Large-volume, Mafic, Potassic Magmatism in SE Brazil, J. Petrol., 36, 189-229, 1995.

Gladczenko, T. P., Hinz, K., Eldholm, O., Meyer, H., Neben, S., and Skogseid, J.: South Atlantic volcanic margins, J. Geol. Soc. London, 154, 465-470, 1997.

Gladczenko, T. P., Skogseid, J., and Eldhom, O.: Namibia volcanic margin, Mar. Geophys. Res., 20, 313-341, 1998.

Gradstein, F., Ogg, J., Schmitz, M., and Ogg, G. 2012.: The Geologic Time Scale 2012, 1. Elsevier, 1176.

Green, R. W. E. and Durrheim, R. J.: A seismic refraction investigation of the Namaqualand Metamorphic Complex, South Africa, J. Geophys. Res. (1978-2012), 95, 19927-19932, 1990.

Hawkesworth, C., Kelley, S., Turner, S., Le Roex, A., and Storey, B.: Mantle processes during Gondwana break-up and dispersal, Journal of African Earth Sciences, 28, 239-261, 1999.

Hinz, K.: A hypothesis on terrestrial catastrophes: wedges of very thick oceanward dipping layers beneath passive continental margins; their origin and paleoenvironmental significance, Schweizerbart, 1981.

Hinz, K., Neben, S., Schreckenberger, B., Roeser, H. A., Block, M., Souza, K. G. d., and Meyer, H.: The Argentine continental margin north of $48^{\circ} \mathrm{S}$ : sedimentary successions, volcanic activity during breakup, Mar. Petrol. Geol., 16, 1-25, 1999.

Hirsch, K. K., Bauer, K., and Scheck-Wenderoth, M.: Deep structure of the western South African passive margin - Results of a combined approach of seismic, gravity and isostatic investigations, Tectonophysics, 470, 57-70, 2009.

Holbrook, W. S., Mooney, W. D., and Christensen, N. I.: The seismic velocity structure of the deep continental crust, Continent. Lower Crust, 23, 1-43, 1992

Jackson, M. P. A., Cramez, C., and Fonck, J.-M.: Role of subaerial volcanic rocks and mantle plumes in creation of South Atlantic margins: implications for salt tectonics and source rocks, Mar. Petrol. Geol., 17, 477-498, 2000.

Kelemen, P. B. and Holbrook, W. S.: Origin of thick, high-velocity igneous crust along the US East Coast Margin, J. Geophys. Res., 100, 10077-10094, 1995.

Koopmann, H., Franke, D., Schreckenberger, B., Schulz, H., Hartwig, A., Stollhofen, H., and di Primio, R.: Segmentation and volcano-tectonic characteristics along the SW African continental margin, South Atlantic, as derived from multichannel seismic and potential field data, Mar. Petrol. Geol., 50, 22-39, 2014.

Koopmann, H., Schreckenberger, B., Franke, D., Becker, K., and Schnabel, M.: The late rifting phase and continental break-up of southern South Atlantic: The mode and timing of volcanic rifting and formation of earliest oceanic crust, Geological Society, London, Special Publications, accepted, 2014. 
Korenaga, J., Holbrook, W. S., Kent, G. M., Kelemen, P. B., Detrick, R. S., Larsen, H.-C., Hopper, J. R., and Dahl-Jensen, T.: Crustal structure of the southeast Greenland margin from joint refraction and reflection seismic tomography, J. Geophys. Res., 105, 21591-21614, 2000.

Korenaga, J., Kelemen, P. B., and Holbrook, W. S.: Methods for resolving the origin of large igneous provinces from crustal seismology, J. Geoph. Res., 107, ECV-1, 2002.

Ludwig, W. J., Nafe, J. E., and Drake, C. L.: Seismic refraction, The sea, 4, 53-84, 1970.

Maystrenko, Y. P., Scheck-Wenderoth, M., Hartwig, A., Anka, Z., Watts, A. B., Hirsch, K. K., and Fishwick, S.: Structural features of the Southwest African continental margin according to results of lithosphere-scale 3D gravity and thermal modelling, Tectonophysics, 604, 104-121, 2013.

Menzies, M. A., Klemperer, S. L., Ebinger, C. J., and Baker, J.: Characteristics of volcanic rifted margins, in: Volcanic Rifted Margins, edited by: Menzies, M. A., Klemperer, S. L., Ebinger, C. J., and Baker, J., Geol. Soc. Am. Spec. Paper, 362, 1-14, 2002.

Mjelde, R., Kasahara, J., Shimamura, H., Kamimura, A., Kanazawa, T., Kodaira, S., Raum, T., and Shiobara, H.: Lower crustal seismic velocity-anomalies; magmatic underplating or serpentinized peridotite? Evidence from the Vøring Margin, NE Atlantic, Mar. Geophys. Res., 23, 169-183, 2002.

Mjelde, R., Shimamura, H., Kanazawa, S., Kodaira, S., Raum, T., and Shiobara, H.: Crustal lineaments, distribution of lower crustal intrusives and structural evolution of the Vøring Margin, NE Atlantic; new insight from wide-angle seismic models, Tectonophysics, 369, 199-218, 2003.

Mjelde, R., Raum, T., Murai, Y., and Takanami, T.: Continentocean-transitions: review, and a new tectono-magmatic model of the Vøring Plateau, NE Atlantic, J. Geodynam., 43, 374-392, 2007.

Mjelde, R., Goncharov, A., and Müller, R. D.: The Moho: Boundary above upper mantle peridotites or lower crustal eclogites? A global review and new interpretations for passive margins, Tectonophysics, 609, 636-650, 2013.

Mohriak, W. U. and Leroy, S.: Architecture of rifted continental margins and break-up evolution: insights from the South Atlantic, North Atlantic and Red Sea-Gulf of Aden conjugate margins, Geological Society, London, Special Publications, 369, 497-535, 2012

Mooney, W. D., Laske, G., and Masters, T. G.: CRUST 5.1: A global crustal model at $5^{\circ} \times 5^{\circ}$, J. Geophys. Res., 103, 727-747, 1998.

Mutter, J. C.: Seaward dipping reflectors and the continent-ocean boundary at passive continental margins, Tectonophysics, 114, 117-131, 1985.

O'Reilly, B. M., Hauser, F., Jacob, A. W. B., and Shannon, P. M.: The lithosphere below the Rockall Trough: wide-angle seismic evidence for extensive serpentinisation, Tectonophysics, 255, 123, 1996.

Peate, D., W.: The Parana-Etendeka Province, Large igneous provinces: Continental oceanic and planetary flood volcanism, edited by: Mahoney, J. and Coffin, M. F., American Geophysical Union, Washington, DC, ETATS-UNIS, 443 pp., 1997.

Peate, D. W., Hawkesworth, C. J., and Mantovani, M. S.: Chemical stratigraphy of the Paraná lavas (South America): classification of magma types and their spatial distribution, Bull. Volcanol., 55, 119-139, 1992.
Peate, D. W., Hawkesworth, C. J., Mantovani, M. M. S., Rogers, N. W., and Turner, S. P.: Petrogenesis and stratigraphy of the highTi/Y Urubici magma type in the Parana flood basalt province and implications for the nature of Dupal-type mantle in the South Atlantic region, J. Petrol., 40, 451-473, 1999.

Planke, S. and Eldholm, O.: Seismic response and construction of seaward dipping wedges of flood basalts: Vøring volcanic margin, J. Geophys. Res., 99, 9263-9278, 1994.

Planke, S., Symonds, P. A., Alvestad, E., and Skogseid, J.: Seismic volcanostratigraphy of large-volume basaltic extrusive complexes on rifted margins. Journal of Geophysical Research: Solid Earth (1978-2012), 105, 19335-19351, 2000.

Rabinowitz, P. D. and LaBrecque, J.: The Mesozoic South Atlantic Ocean and Evolution of Its Continental Margins, J. Geophys. Res., 84, 5973-6002, 1979.

Ridley, V. A. and Richards, M. A.: Deep crustal structure beneath large igneous provinces and the petrologic evolution of flood basalts, Geochemistry, Geophysics, Geosystems, 11, Q09006, doi:10.1029/2009gc002935, 2010.

Rudnick, R. L. and Fountain, D. M.: Nature and composition of the continental crust: A lower crustal perspective, Rev. Geophys., 33, 267-310, 1995.

Schinkel, J.: Tiefenstruktur der Kontinent-Ozean-Grenze vor dem Orange Fluss, Namibia, Master Thesis, Institut für Geowissenschaften der Friedrich-Schiller Universität, Jena, Jena, 2006.

Schnabel, M., Franke, D., Engels, M., Hinz, K., Neben, S., Damm, V., Grassmann, S., Pelliza, H., and Dos Santos, P. R.: The structure of the lower crust at the Argentine continental margin, South Atlantic at $44^{\circ} \mathrm{S}$, Tectonophysics, 454, 14-22, 2008.

Sibuet, J.-C., Hay, W. W., Prunier, A., Montadert, L., Hinz, K., and Fritsch, J.: Early evolution of the South Atlantic Ocean: role of the rifting episode, Initial Rep. Deep Sea Drill. Proj., 75, 469481, 1984.

Stankiewicz, J., Parsiegla, N., Ryberg, T., Gohl, K., Weckmann, U., Trumbull, R., and Weber, M.: Crustal structure of the southern margin of the African continent: Results from geophysical experiments, J. Geophys. Res., 113, B10, doi:10.1029/2008JB005612, 2008.

Talwani, M. and Abreu, V.: Inferences regarding initiation of oceanic crust formation from the US East Coast margin and conjugate South Atlantic margins, in: Atlantic Rifts and Continental Margins edited by: Mohriak, W. U. and Talwani, M., Geophysical Monograph Series, Am. Geophys. Union, Washington, DC, 211-234, 2000.

Thybo, H. and Artemieva, I. M.: Moho and magmatic underplating in continental lithosphere, Tectonophysics, 609, 605-619, 2013.

Trumbull, R., Harris, C., Frindt, S., and Wigand, M.: Oxygen and neodymium isotope evidence for source diversity in Cretaceous anorogenic granites from Namibia and implications for A-type granite genesis, Lithos, 73, 21-40, 2004.

Trumbull, R. B., Sobolev, S. V., and Bauer, K.: Petrophysical modeling of high seismic velocity crust at the Namibian volcanic margin, in: Volcanic Rifted Margins, edited by: Menzies, M. A., Klemperer, S. L., Ebinger, C. J., and Baker, J., Boulder, Colorado, Geol. Soc. Am. Spec. Paper 362, 225-234, 2002.

Trumbull, R. B., Bühn, B., Romer, R. L., and Volker, F.: The Petrology of Basanite-Tephrite Intrusions in the Erongo Complex and Implications for a Plume Origin of Cretaceous Alkaline Complexes in Namibia, J. Petrol., 44, 93-112, 2003. 
Trumbull, R. B., Reid, D. L., de Beer, C., van Acken, D., and Romer, R. L.: Magmatism and continental breakup at the west margin of southern Africa: A geochemical comparison of dolerite dikes from northwestern Namibia and the Western Cape, S. Afr. J. Geol., 110, 477-502, 2007.

Voss, M. and Jokat W.: Continent-ocean transition and voluminous magmatic underplating derived from $P$ wave velocity modelling of the East Greenland continental margin, Geophys. J. Int., 170, 580-604, 2007.

Voss, M., Schmidt-Aursch, M. C., and Jokat, W.: Variations in magmatic processes along the East Greenland volcanic margin, Geophys. J. Int., 177, 755-782, 2009.
White, R. and McKenzie, D.: Magmatism at Rift Zones: The Generation of Volcanic Continental Margins and Flood Basalts, J. Geophys. Res., 94, 7685-7729, 1989.

White, R. S. and Smith, L. K.: Crustal structure of the Hatton and the conjugate east Greenland rifted volcanic continental margins, NE Atlantic, J. Geophys. Res., 114, B5, doi:10.1029/2008JB005856, 2009.

White, R. S., Spence, G. D., Fowler, S. R., McKenzie, D. P., Westbrook, G. K., and Bowen, A. N.: Magmatism at rifted continental margins, Nature, 330, 439-444, 1987.

White, R. S., Smith, L. K., Roberts, A. W., Christie, P. A. F., and Kusznir, N. J.: Lower-crustal intrusion on the North Atlantic continental margin, Nature, 452, 460-464, 2008. 